\title{
28055. Marxist Approaches to Social Work
}

\section{Author and Contact Information}

Dr Tom Vickers

Northumbria University

Department of Social Sciences and Languages

Newcastle

NE1 8ST

E-mail: tom.vickers@northumbria.ac.uk

Telephone: 01912273693

\section{Abstract}

This chapter explores the diversity within Marxist approaches to social work, outlining key aspects of Marxism and the implications for social work under capitalist states, in situations where states break down, and under socialist states. Within each of these contexts, key examples are explored to demonstrate the range of approaches taken. The entry argues that there has been a neglect in the English-language literature of Marxist approaches to social work under socialism, and suggests that recent moves to open up the definition of social work through the concept of 'popular social work' offer one approach to begin filling this gap.

\author{
Keywords \\ socialism \\ capitalism \\ Britain \\ United States \\ China \\ Cuba \\ popular social work \\ radical social work \\ state \\ welfare \\ human services \\ healthcare \\ education \\ politics \\ dialectical materialism
}

\section{Introduction}

English-language writing on Marxist social work has generally been limited to the 'Radical Social Work' tradition (e.g. Corrigan and Leonard, 1978; Reisch and Andrews 2001; Lavalette, 2011) and 
has neglected much of the diversity within Marxism including the experience of socialist countries (the limited English-language literature includes Oanh, 2002; Strug, 2006; Yip, 2005). A comprehensive coverage of Marxist approaches to social work is beyond the scope of this entry. Instead I outline the key features of Marxist understandings of society and the implications for social work under capitalist states, in situations where states break down, and under socialist states. Within each of these contexts, key examples are explored, following Marxism's attention to concrete conditions. The entry is written from a Marxist, specifically Leninist, perspective. I have attempted to give a fair account of other trends, and to be open about my standpoint to support a critical engagement.

\section{Marxist understandings of society}

'Marxism is many things...in a state of flux and development, and is subject to highly divergent interpretations...Marxism is not simply a theory: it is a political practice which confronts capitalism with an alternative model of a social order' (Corrigan and Leonard, 1978: xiii-xiv). Marxism is thus unfinished, containing theory and practice in a dialectical unity, 'praxis' (Lenin, [18951916] 1972: 103). Marxism presents a systemic view that can help social workers relate the personal to the social in order to address the root causes of people's problems, an aim shared by some feminist and anti-racist approaches.

\section{Dialectical Materialism}

The Marxist analytic method, dialectical materialism, involves an iterative movement from holistic and concrete living phenomena to a 'number of determinant, abstract, general relations' and from there back to a more complex understanding of the living whole (Marx, [1857] 1973: 100-102). Marxism focuses on the shaping of consciousness by experience, shaped in turn by the way society is organized, with its most basic roots in processes of production and reproduction. Marxism's central premises are that people must produce to survive, that the satisfaction of needs leads to further needs, that people reproduce not only themselves but their species, and that all of this activity is organized socially, depending on the means of production available. Dialectical materialism is distinguished from crude materialism by its acknowledgement that history is determined by not only the economic class struggle, but also 'the legal, political, religious, artistic or philosophic - in short, ideological forms in which men (sic) become conscious of this conflict and fight it out' (Marx, [1859] 1971: 21), with ideas impacting back on the future development of the material basis of society. In one example of the application of this to social work, Corrigan and Leonard (1978: 129-132) suggest 
that migrant families within Britain can be better understood in the context of the relations of production in their country of origin, and how these interact with relations of production within Britain. Such understandings enhance agency by developing an understanding of how structural conditions shape and limit individual behaviour.

\section{Class struggle}

Marxism is not the only approach focusing on class, but Ferguson (in Lavalette, 2011: 128-9) distinguishes Marxism by its attention to inequalities in the ownership of the means of production, as opposed to simply in distribution, and exploitation as opposed to simply domination, with the contradictions and consequent struggle between exploiters and exploited driving the development of society.

In some cases racialized, gendered, and other forms of oppression have been neglected by Marxists, subsumed within a homogenous view of the working class that is implicitly white, male, heterosexual, in paid employment and able-bodied, and critiques of this neglect have contributed to more complex understandings of class (e.g., Dixon, et al. in Craig, et al., 1982; Meagher and Tett in Cooke and Shaw, 1996). However, this neglect is not fundamental to Marxism. Anderson (2010) shows that Marx himself devoted considerable attention to 'race', and many Marxists have continued in this tradition. For example Chandler Owen, the recipient of one of the first social work fellowships in the US, linked capitalism to racism, supported unionization of black labour, and was the leader of the Political Council, which was the only African American political group to come out in support of women's suffrage (Reisch and Andrews, 2001: 44-5). In a long-running debate within Marxism, Clough (1992) argues that the sidelining of 'race' and gender within some approaches to Marxism reflects the narrow interests of a minority of predominantly white, male and 'skilled' workers in capitalist countries, who are afforded relative privileges on the basis of their countries' imperialist position in the global economy, receiving super-profits from the exploitation of the workers and resources of oppressed countries (Callinicos, 2009 gives an opposing view).

\section{The politics of social work}

Marxism suggests that social work is inherently political:

'conventional practice is fully political, whether or not its politics are acknowledged. The ends it serves, however, are conservative ones. Radicals do not seek to introduce politics into an 
apolitical situation. Rather we mean to challenge the politics of compliance and to introduce the politics of resistance and change' (Galper, 1980: 10-11).

For example, Lavalette and loakimidis (in Lavalette and loakimidis, 2011: 142-6) point to the political role of the US-backed international expansion of social work in Western Europe and Asia following the second world war as part of the Marshall plan, 'the goal of which was to make the countries "safe" for Western capitalism and establish a social and political bulwark against Communist expansion', first through United Nations Reconstruction and Rehabilitation Agency and then the American Rehabilitation Missions. Similarly, the first professional training programmes for Nicaraguan social workers were established in the early 1960s, following the Cuban Revolution 'to promote a model of development in the region intended to reduce social discontent and prevent further such revolutions' (Wilson and Hernández in Lavalette and loakimidis, 2011: 77). In such a context, for social workers to fail to consciously adopt a political position leads to tacit complicity with the status quo, which serves the interests of the dominant class.

\section{The state}

Marxists differ in their understanding of the capitalist state, its capacity for reform, and if it must be abolished then what should replace it. They agree in viewing the class character of the state as important in creating the conditions under which social work operates. Lenin ([1917] 1972: 8) defines the state as an institution emerging in the midst of class struggle as a means of holding in check irreconcilable antagonisms in order to stabilize the system. In this view, the state emerges as the organ of the most powerful, economically dominant class, who, through the exercise of a state apparatus specifically tailored to its needs, maintains itself as the politically dominant class within a given geographical territory (Lenin, [1917] 1972: 13-14). Another important Marxist theorist of the state is Gramsci ([1929-1935] 1982), who analysed the dialectical relationship between consent and coercion in the modern capitalist state, and has been particularly influential within western academia. Disagreements with the Leninist conception of the state typically concern arguments that the British state either enjoys 'relative autonomy' from capitalist pressures, and is neutral with regard to different sections of society, to be fought over by competing interest groups, or that it is not coherent, with different interests served by different sections of the state. The latter argument has been associated historically with the Fabians in the British Labour Party, who differentiate between a 'good' side of the capitalist state, including social services, health, education and nationalized industries, and a 'bad' side, including defence, law and order, and aid to private industry (LEWRG 1980: 52-3). 
Among Marxists who understand the capitalist state as irredeemably anti-working class, there is a divergence between 'libertarian' or 'autonomous' trends, which reject any kind of state, and those who argue a socialist state is needed to facilitate a transition to a classless society. Within the latter, there is a further division as to what constitutes socialism, with different Marxists categorising the same states as 'socialist', 'state capitalist', or 'degenerate/deformed workers' states' (Galper, 1980: 29-39). The class character of the capitalist and socialist state implies a need for a different kind of social work under each. This is connected to:

- Socialism's claims to overcome the root causes of the social problems social work seeks to address rather than simply manage their consequences (Strug, 2006);

- The role of socialist state, political and 'mass' organisations in tackling the same issues social work seeks to address (Oanh, 2002);

- Contradictions between professional ideals of individual autonomy and socialist ideals of collective political leadership (Ngai, 1996).

It is a point of contention in the historiography of social work whether social work was unnecessary in countries attempting to build socialism because the problems it sought to address did not exist, at least not to the same extent as under capitalism, or whether the existence of those problems was simply denied by political leaderships lacking in reflexivity, or whether social work continued under socialism, but in different forms and with different personnel (Ngai, 1996: 293). The reality may be a mixture of all three, in different measures in different countries at different times.

\section{Social work under capitalism}

Because Marxism poses a threat to the capitalist state, for social workers to openly declare their Marxism may jeopardize their employment and with it their ability to practice Marxist social work. Although Marxist social work academics often have greater freedom than practitioners, there has still been a tendency to avoid explicitly discussing their underlying Marxist method. The Critical and Radical Social Work journal launched in 2013 is typical in not mentioning Marxism in its title or aims despite being edited by committed Marxists. The most public face of Marxist social work under capitalism has been as an influential strand within the 'Radical Social Work' (RSW) tradition. In the US, Reisch and Andrews (2001) trace RSW's history back through the Rank and File Movement of the 1930s, led by Marxists such as Bertha Reynolds, who 'warned that unless New Deal policies moved beyond "offering palliatives to assuage the miseries of poverty and racism," social workers would do little more than "carry out the designs of the ruling class and victimize clients"' (Reynolds cited in 
Reisch and Andrews, 2001: 79). Similar histories exist in other countries, such as the East London Federation of Suffragettes, founded in Britain in 1914 by the communist Sylvia Pankhurst, which organized cost price restaurants, nurseries and other services alongside political agitation. In the 1970s economic crisis increased antagonisms between the state and service users in some countries, prompting a growth in RSW including a practitioner movement around the CaseCon manifesto and magazine in Britain; organisations such as 'Inside Welfare' in Australia; and publications such as Galper (1980) in the US; and Bailey and Brake (1975) and Corrigan and Leonard (1978) in Britain. The history of RSW is contested, seen as either dying out with the defeat of working class struggles in the 1980s (Langan and Lee, 1989) or developing into anti-racist, black and feminist approaches in response to Marxists' failure to respond adequately to racism, sexism and other forms of oppression that intersect with class (Dominelli, 1989). In the early twenty-first century RSW returned to prominence as a distinct approach, with publications such as Lavalette (2011) and the founding of the Social Work Action Network (SWAN) in Britain, connected to similar organisations in countries as diverse as Hungary, Japan and the US (Lavalette and Ferguson, 2011. The discussion here will focus on Britain and the US, both because they have a more extensive English-language RSW literature and because of their impact on RSW internationally. In Britain a complicated history between social work and community work led to a distinct strand of 'radical community work' (e.g. Craig et al., 1982), part of social work in many countries, and this branch of the tradition offers important contributions that are included here. I focus on the more or less explicitly and self-consciously Marxist elements within RSW, while acknowledging Marxism's wider impact, including within service user movements that have developed alongside RSW (Beresford in Lavalette, 2011: 96-7), and recognising that many social work writers draw on Marxism without explicitly discussing Marxist theory.

The central problem driving the development of RSW is the contradictory character of capitalist state welfare, simultaneously ensuring a healthy and compliant workforce, managing the behaviour of the working class (including attempts to undermine resistance to exploitation), and also providing important material resources for working class people that often represent concessions won from the capitalist class through hard struggle. Jones and Novak (1999: 79-80) point out, as many others within RSW have done, that state social work interventions are almost exclusively targeted at the poorest in society, who have 'the most marginal if any relationship to waged labour' and who are therefore regarded by the capitalist class as a surplus population to be managed. Stevenson (1978) suggests that while elements of service and control are inherent in all areas of 'human services', including social work, the balance is different for different groups, with the example that 


\footnotetext{
'the service aspect is dominant in New York City schools when teachers teach white middleclass students. The control aspect is dominant when they teach black and Latino workingclass students'. (Stevenson, 1978: 459)
}

In a concise article that moves beyond many of the classic social work texts in its treatment of the political economy of welfare work, Stevenson (1978: 457-459) argues that 'human services' labour represents production of a special kind, involving direct contact between producer and consumer that opens up possibilities for solidarity through human contact but operating in a context where there is a material incentive for human service workers to maintain dependency among service users to ensure continuing demand for their 'product'. While Marxists are not alone in arguing that dependency should be avoidable, Marxist approaches offer an explanation of the tendencies within capitalist state welfare that pull social workers in contradictory directions, to side with service users in a struggle to overturn the basis of their oppression, requiring at times a willingness to confront the capitalist state, and to cooperate with the state in managing service users' responses to their oppression within limits that will not disrupt the fundamental structures of capitalist society.

There has been a divide within Marxist social workers over how to respond to the contradictions outlined above, centred on whether social work is simply a mechanism of social control, with little or no potential to contribute to progressive change, or whether there is potential to subvert ruling class priorities for social work and develop progressive practice within the capitalist state. RSW has predominantly represented the latter perspective, informed by an understanding of the state as 'semi-autonomous' (LEWRG, 1980), containing contradictions and reflecting the class struggle and the balance of forces at a particular point, and therefore capable of shifting its priorities in response to pressure from a strong and organized working class. This implies spaces within the state, created by the class struggle, for socialist practice, which can in turn support further advances in the class struggle. RSW theorists such as Corrigan and Leonard (1978: 106) and Jones and Novak (1999: 154-5) point out that compared to civil servants or employees of large state bureaucracies, social workers and other welfare professionals have a degree of autonomy in their day to day work that makes it difficult for the state to monitor and control them, even if this autonomy has been reduced in many countries through increasing bureacratization of social work and closer supervision (Garrett, 2009).

Some Marxists argue the aims of RSW should not focus on solving individuals' problems, but on highlighting the contradictions that they demonstrate and raising political consciousness about their wider causes as a basis for forming alliances that could achieve structural change (Cooke in Cooke and Shaw, 1996: 6-25). This approach calls for education alongside organisation, recognising that 
'the development of a fuller political analysis can only be achieved by the introduction of systematic reflection and more structured educational opportunities within the community work process' (Cooke in Cooke and Shaw, 1996: 20-21). Others argue that there is not necessarily a contradiction between Marxist social work and meeting immediate needs, but rather that RSW needs to link the personal and immediate with the collective and the long-term:

'If counselling is required, it must be provided. But if...counselling...fails...to link...temporary and partial solutions with the larger social transformation that is required for realistic solutions, then it is extremely limited, at best, and deceptive and repressive, at worst' (Galper, 1980: 12-13).

Following this approach, standard processes of referral might be reinterpreted to include workers 'investigating appropriate political resources in the community and determining their relevance to the particular issues faced by those with whom we work' (Galper, 1980: 137). RSW advocates have argued that as well as more overtly political activities, such as political education and organising, social work also has an important role to play in supporting people to sustain their involvement in collective struggle. For example, Bailey and Brake (1975: 9-10) argue for the need to help people overcome the 'psychological damage' which may result from resisting capitalist hegemony. Baldock (in Craig et al., 1982: 30) draws on work with single parents to argue that radical social work can foster strong mutual caring to support political activity by sections of the working class who are normally excluded from political activity by the pressures of their personal circumstances.

Questions regarding the relative importance of workplace and community struggles, and the relationship between them, have been contested within RSW. This reflects a contradiction between the emphasis on trade union struggles within dominant trends in the broader Marxist movement in countries such as Britain, Canada and the United States, and the daily contact between social workers and sections of the working class facing oppression outside the workplace, and at times engaged in significant struggle there, such as the movement against the Community Charge, known popularly as the 'Poll Tax', in Britain in the late 1980s and 1990s. Corrigan and Leonard (1978: 142-7) are typical of the dominant trend in the wider Marxist left in these countries when they interpret an alliance between social workers and the working class as meaning 'the trade unions must come into the forefront of all those involved in campaigns against the welfare cuts at a local and national level', because 'they represent the only powerful force that has struggled and will continue to struggle against the cuts in the welfare state'. The authors acknowledge the existence of only two trends within Marxism on the question of trade unions, both of which assert that trade unions must be the pre-eminent working-class organisational form, and differ only on the emphasis placed on the rank 
and file versus the leadership. This view neglects the work of Marxist theorists such as Lenin ([1917] 1972) and Gramsci ([1929-35] 1982) who have written extensively on the limitations of trade union politics and the potential for their cooption by the ruling class. Corrigan and Leonard note the limitations of unions, that 'by themselves [they] are not revolutionary or potentially revolutionary organisations of the working class', but argue this has a historical and cultural, but not material, basis, and can therefore be changed through a long period of persuasion (142-7; for an alternative view on British trade unions see Clough 1992). Stevenson (1978) points to the dual character of human service workers' role as both oppressed workers and agents of oppression toward other working class people, which creates the potential for a material divide between the immediate material interests of social workers represented by their trade unions and the interests of other sections of the working class using their services, so that:

'certain struggles of progressive elements among human service workers (i.e. those around traditional bread-and-butter issues such as higher salaries and better working conditions, as well as more fundamental struggles around democratization and control) may not have any bearing on their role as oppressors' (Stevenson, 1978: 460).

In a recent example, in June 2013 Britain's biggest public sector union, Unison, issued a circular to branches instructing its members to implement a cut to rent payments for social housing tenants assessed as having one or more unused bedrooms, popularly dubbed the 'bedroom tax', lest Unison members jeopardise their employment.

Some RSW writers place greater emphasis on organising outside unions. Galper (1980: 198-212) considers possibilities for organising with other social workers inside and outside unions, where possible with other workers sharing 'socialist commitments'. Cooke (in Cooke and Shaw 1996: 11) argues that although building links with the trade union movement and Labour Party were central to the aims of many radical community workers in Britain in the 1970s, this was often not achieved in practice, and cites factors including the often 'lukewarm response from Trade Union representatives' and the fact that many community campaigns of the period were forced to confront Labour governments and Labour-controlled local authorities. Fleetwood and Lambert (in Craig et al., 1982: 48-58) discuss the disconnect between socialist community workers' experience of housing struggles, in particular from 1975, and the orthodoxy of socialist practice in Britain, which 'scorned non-workplace struggles' and 'exhorted activists to link up with trade unions and trades councils in the muscle of the labour movement', even in a period where 'the very existence...of a labour movement can be seriously doubted' (49). Accusations of neglect of racism and sexism also contributed to the fragmentation of struggles in and against the state. Fleetwood and Lambert argue 
that the lack of engagement between socialist community workers and community struggles lead to the left critique of the limits of spontaneous community action becoming a self-fulfilling prophesy, since:

'divorced from socialism, denied legitimacy by the labour movement, such work has tended to be small-scale, cautious, uncoordinated and individualistic.' (Fleetwood and Lambert in Craig et al., 1982: 50).

Against this the authors propose a form of socialist practice that:

'starts and grows with the experience of people in struggle...developing techniques, organisational forms and relationships which recognize the personal barriers (constructed by capitalist society) to a class consciousness....it will entail people to do extraordinary things, to dress up, sing songs, perform antics in council chambers, to travel unprecedented distances.' (Fleetwood and Lambert in Craig et al., 1982: 57).

This history of debates within RSW can be drawn upon to inform social work practice today.

\section{Social work where the state breaks down}

Lavalette and laoakimidis (2011) use the term 'popular social work', encompassing welfare activities provided by communities and social movements, including situations where states break down or are unable to cope, whether as a result of war, revolution or natural disaster.There is a rich tradition of welfare services as part of anti-capitalist struggles, dating back to Karl Marx, who organised committees to support fellow German refugees after his arrival in London in 1848 . The most significant international efforts include the International Organisation for the Support of Fighters for the Revolution (MOPR), known in many countries as International Red Aid, founded in 1922 (Schilde in Hering and Waaldijk, 2003: 140), and Cuba's internationalism in education, sport and healthcare since 1959 (Yaffe, 2009). MOPR supported communists imprisoned, injured or killed in the course of political activity, together with their families, through 'legal counselling, social welfare for prisoners [including cash, clothing and food for their families], children's homes, support for campaigns directed at the liberation of communist political prisoners and support for political refugees' (Schilde in Hering and Waaldijk, 2003: 144). Red Aid activities varied from country to country, and sometimes went far beyond support for political prisoners, for example in the early 1920s the Swiss section provided free contraceptives and advice (Hering in Hering and Waaldijk, 2003: 91).

Welfare activities were also organized by communists during periods of revolutionary warfare, for example: 
- from the 1930s the 'patriotic and revolutionary Vietnamese tried to build networks of youth, students, workers (horse-cart drivers, carpenters, shoe-makers, porters) in the form of "red relief services" to serve the poor and provide mutual assistance' (Oanh 2002: 85);

- from 1940-1944 in Greece, under Nazi occupation the communist-led EAM (National Liberation Front) developed welfare provision based on grassroots democracy and solidarity, encompassing 'the fight for survival, popular administration and "holisitic development"' (loakimidis in Lavalette and loakimidis, 2011: 115-32).

\section{Social work under socialism}

I use the term socialism to represent a method for organising society rather than a blueprint for utopia, characterized by social ownership of the means of production, a high degree of democratic participation, and prioritization of quality of life and conditions for each individual to flourish (Galper, 1980: 29-39). The characterization of countries as socialist is widely contested, but has included the countries in Africa, Asia, Europe and America (Galper, 1980: 29-30). . The limited literature that exists on social work under socialism shows the diversity of approaches and suggests there would be much to be gained from further research in this area, illustrated by the following brief case studies of the changing role of social work in China and Cuba.

In China, professional social work was abolished in the 1950s along with other social sciences that were judged unsuited to socialism because they developed under capitalism. Ngai (1996: 292) argues that professional social work's re-emergence in the 1980s was driven by social problems consequent on China's transition to a market economy. During the socialist period social work took fundamentally different forms within the context of a wider revolutionary process aimed at advancing human welfare. Ngai (1996: 293) describes a range of organisations playing 'social work service' roles, including the Ministry of Civil Affairs and mass organisations such as the All-China Federation of Trades Unions, the Chinese Communist Youth League, the All-China Federation of Youth and the All-China Federation of Women. There is also a strong resonance between social work and healthcare developments during the Cultural Revolution from 1964, which aimed to generalize medical knowledge to the whole population through the 'barefoot doctors' movement, equipping people with the skills to care for themselves and one another, alongside advances in professionalized specialist care. In mental health care there was a movement in the early years of the Revolution away from institutionalisation and medical approaches to a range of individual and 
collective approaches focusing on rehabilitation wherever possible, the abolition of restraint and combining Western and Chinese practices developed under capitalism with new methods including therapy through productive work and other activities (Yip, 2005: 108). During the Cultural Revolution the political character of psychiatric treatment was intensified, with mental illnesses viewed as inseparable from the damage done to individuals by capitalism. Forms of treatment included: mutual support between patients; 'self-reliance', meaning that patients should be actively engaged in investigating their conditions and understanding their treatment; political education classes, led by a patient member of the group; and open self- and mutual-criticism. Critics argue that psychiatric confinement was also used during this period as a political weapon against opponents of the Revolution's leadership (Yip, 2005: 108-110).

In Cuba, in the first few years after the 1959 revolution, mass organisations took on social work roles. For example, the Cuban Federation of Women described its members as 'empirical social workers', who:

'facilitated the entry of women into the labor market, promoted their economic, political and social involvement with the Revolution, and organized community members for participation in major educational and public health initiatives' (Strug, 2006: 751-2). When professional social work was reintroduced, through technical training institutes from 1973, it was as assistants to healthcare workers (Strug, 2006: 752). In the 1990s, the extreme hardships of the 'special period' following the collapse of the Soviet Union, the tightening US blockade, and social problems fuelled by the re-introduction of tourism such as drugs and prostitution that were, led social workers to target particularly at-risk sections of society, including pregnant women and older people. These social workers became increasingly involved in the People's Councils that were intended to act as a bridge between municipalities and local communities, 'comprised of community delegates, mass organizations and administrative entities', while also maintaining strong links to medical practitioners and the Communist Party (Strug, 2006: 753-755). Social workers engaged in community organising, built community members' capacity to participate in the People's Councils, and advocated for specialist services for at-risk groups. Strug (2006) cites an interview with a Cuban social work educator who described how these practice developments drove educational reforms, including the creation of a six-year social work degree programme within the Department of Sociology at the University of Havana in 1998:

'We had to change our way of training social workers. We needed an educational program that would teach them how to work with Committees for the Defense of the Revolution and 
the Federation of Cuban Women [mass organizations], delegates [local elected officials], school teachers, and out-of-school-kids' (Strug, 2006: 755).

This was followed by the creation of paraprofessional social work schools to train out-of-school and unemployed youth, who had grown up during the special period, to work in Cuba's poorest neighbourhoods, according to one social work student to become 'friends of the family, knocking on doors not touched by the Revolution', as part of a 'Battle of Ideas' that aimed to strengthen Cuba 'economically, socially and ideologically' (Strug, 2006: 757). Strug (2006) places Cuban social work in the context of socialism, reflecting:

'the fact that the central government in Cuba has for half a century promoted collective goals and community ties, and has involved local self-government in the management of neighborhood affairs' (Strug, 2006: 758).

Bertera (2003) describes Cuban work with older people that combines health, social work and geriatric professionals, integrated within the community and sustained by 'broad community participation', not as an act of charity but as 'organized community action' in concert with the state. Voluntary work is widespread and is seen as a social duty, 'one of the ideological pillars of society', and a resource on which social workers draw in their work (Bertera, 2003: 319). This demonstrates a role for social workers as organizers of people to meet one another's needs as part of a socialist process together with the state, contrasting with social work under capitalism to resist class attacks on working class people by the state or to mitigate their most damaging effects.

\section{Conclusion}

Marxism emphasizes that realising subjective agency, for practitioners and services users, requires analysis of the constraints imposed by objective conditions. Under capitalism, social work can help facilitate social change, through political education, building alliances between oppressed groups, and helping people to cope with the alienation and exploitation caused by capitalism while they struggle to change oppressive structures. Under socialism, a radical shift in approach is needed for social work to retain its relevance, as Radical Social Work's goals of organising society to meet human needs are no longer marginal or oppositional, but are pursued by a socialist state and political and mass organisations tailored to that purpose. At the same time, professional autonomy threatens to compete with the political leadership of the revolution. Approaches to social work and welfare in countries where Marxist-led revolutions have attempted to build socialism offer a rich source of experience, but are under-documented in English. Recent steps toward broadening what constitutes social work, through the concept of 'popular social work', represent a step forward in 
comparing social work approaches under such radically different contexts as capitalist states, states that are breaking down or fundamentally contested, and socialist states.

\section{Cross References}

28018. community work

28035. Global Agenda

28053. 'man-made' and natural disasters

28062. neoliberalism

28074. radical social work

28088. social work in China

28089. social work in Eastern Europe

28090. social Work in Latin America

28091. social work in Russia

28096. trade unions

\section{References}

Anderson, K. B. (2010). Marx at the margins: on nationalism, ethnicity, and non-western societies. Chicago, IL: University of Chicago Press.

Bailey, R. and Brake, M. (eds.) (1975). Radical social work. London: Edward Arnold.

Bertera, E. M. (2003). Social services for the aged in Cuba. International Social Work 46(3), 313-321.

Callinicos, A. (2009). Imperialism and the global political economy. Cambridge: Polity.

Clough, R. (1992) Labour: a party fit for imperialism. London: Larkin Publications.

Cooke, I. and Shaw, M. (eds.) (1996). Radical community work: perpsectives from practice in

Scotland. Edinburgh: Moray House Institute of Education.

Corrigan, P. and Leonard, P. (1978). Social work practice under capitalism: a Marxist approach. London: MacMillan.

Craig, G., Derricourt, N. and Loney, M. (eds.) (1982). Community work and the state: towards a radical practice. London: Routledge and Kegan Paul.

Dominelli, L. (1989). Feminist social work. Oxford: Macmillan Education.

Galper, J. (1980). Social work practice: a radical perspective. Englewood Cliffs, NJ: Prentice-Hall.

Garrett, P.M. (2009). 'Marx and 'Modernization' Reading Capital as Social Critique and Inspiration for Social Work Resistance to Neoliberalization' Journal of Social Work 9(2), 199-221.

Gramsci, A. ([1929-1935] 1982). Selections from the prison notebooks. London: Lawrence and Wishart.

Hering, S. and Waaldijk, B. (eds.) (2003). History of social work in Europe (1900-1960): female pioneers and their influence on the development of international social organizations. Wiesbaden: GWV Fachverlage $\mathrm{GmbH}$.

Jones, C. and Novak, T. (1999). Poverty, welfare and the disciplinary state. London: Routledge.

Langan, M. and Lee, P. (eds.) (1989). Radical social work today. London: Unwin Hyman.

Lavalette, M. (ed.) (2011). Radical social work today: social work at the crossroads. Bristol: The Policy Press.

Lavalette, M. and Ferguson, I. (eds.) (2011). International social work and the radical tradition. Birmingham: Venture Press.

Lavalette, M. and loakimidis, V. (eds.) (2011). Social work in extremes: lessons for social work internationally. Bristol: The Policy Press. 
Lenin, V. I. ([1895-1916] 1972). Philosophical notebooks. London: Lawrence and Wishart.

Lenin, V. I. ([1917] 1972). The state and revolution. Moscow: Progress Publishers.

LEWRG, London Edinburgh Weekend Return Group (1980). In and against the state. London: Pluto Press.

Marx, K. ([1857] 1973). Grundrisse. London: Penguin.

Marx, K. ([1859] 1971). A contribution to the critique of political economy. London: Lawrence and Wishart.

Ngai, N. P. (1996). Revival of social work education in China. International Social Work 39(3), 289300.

Oanh, N. T. (2002). Historical development and characteristics of social work in today's Vietnam. International Journal of Social Welfare 11(1), 84-91.

Reisch, M. and Andrews, J. (2001). The road not taken: a history of radical social work in the United States. Philadelphia, PA: Brunner-Routledge.

Stevenson, G. (1978). Social relations of production and consumption in the human service occupations. International Journal of Health Services 8(3), 453-463.

Strug, D. (2006). Community-oriented social work in Cuba: government response to emerging social problems. Social Work Education 25(7), 749-762.

Yaffe, H. (2009). Cuban development: inspiration for the Bolivarian Alliance for the Americas (ALBA). Journal of Iberian and Latin American Research 15(2), 145-162.

Yip, K. S. (2005). An historical review of the mental health services in the People's Republic of China. International Journal of Social Psychiatry 51(2), 106-118.

\section{Relevant Websites (all accessed December 2012)}

Barefoot Social Worker list of radical social work texts, http://www.radical.org.uk/barefoot/

Marxist Internet Archive, http://marxists.org/

Social Work Action Network (SWAN), http://www.socialworkfuture.org/

Social Work and Social Policy in Cuba, http://www.redandgreen.org/Cuba.htm

The Rank-and-Filer, political analysis for radical social service workers, http://www.rankandfiler.net 